\title{
ON GENERALIZED STRONGLY NONLINEAR VARIATIONAL-LIKE INEQUALITIES
}

\author{
Zeqing Liu, Juhe Sun, Soo HaK Shim and Shin Min Kang
}

\begin{abstract}
The purpose of this paper is to introduce and study a new class of generalized strongly nonlinear variational-like inequalities. The existence and uniqueness of solution and a new iterative algorithm for the generalized strongly nonlinear variational-like inequality are proved and suggested, respectively. Moreover, the convergence criteria of the sequence generated by the iterative algorithm are also given.
\end{abstract}

Mathematics subject classification (2000): 47J20, $49 \mathrm{~J} 40$. algorithm

Keywords and phrases: Generalized strongly nonlinear variational-like inequality, contraction mapping,

\section{REFERENCES}

[1] S. S. CHANG, Variational inequalitity and complementarity theory with applications, Shanghai Sci. Technol., Shanghai (1991).

[2] S. S. Chang, On the existence of solutions for a class of quasi-bilinear variational inequalities, J. Sys. Sci. Math. Scis. 16 (1996), 136-140 [In Chinese].

[3] P. CUBiotTI, Existence of solutions for lower semicontinuous quasi equilibrium problems, Computers Math. Appl. 30 (1995), 11-22.

[4] X. P. DING, Algorithm of solutions for mixed nonlinear variational-like inequalities in reflexive Banach space, Appl. Math. Mech. 19 no. 6 (1998), 521-529.

[5] X. P. DING, Existence and algorithm of solutions for nonlinear mixed variational-like inequalities in Banach spaces, J. Comput. Appl. Math. 157 (2003), 419-434.

[6] X. P. DinG, K. K. TAN, A minimax inequality with applications to existence of equilibrium point and fixed point theorems, Colloq. Math. 63 (1992), 233-247.

[7] I. Ekeland, R. Temam, Convex Analysis and Variational Problems, North-Holland, Amsterdam, Holland (1976).

[8] N. J. HUANG, C. X. DENG, Auxiliary principle and iterative algorithms for generalized set-valued strongly nonlinear mixed variational-like inequalities, J. Math. Anal. Appl. 256 (2001), 345-359.

[9] L. S. LiU, Ishikawa and Mann iterative process with errors for nonlinear strongly accretive mappings in Banach spaces, J. Math. Anal. Appl. 194 (1995), 114-125.

[10] Z. LIU, J. S. UME AND S. M. KANG, Nonlinear variational inequalities on reflexive Banach spaces and topological vector spaces, Internat. J. Math. and Math. Sci. 2003 no. 4 (2003), 199-207.

[11] Z. LiU, L. Debnath, S. M. Kang AND J. S. Ume, Completely generalized multivalued nonlinear quasi-variational inclusions, Internat. J. Math. and Math. Sci. 30 no. 10 (2002), 593-604.

[12] Z. LIU, L. DEBNATH, S. M. KANG AND J. S. UME, On the generalized nonlinear quasi-variational inclusions, Acta. Math. Informatica Universitatis Ostraviensis 11 (2003), 81-90.

[13] Z. LiU, L. Debnath, S. M. KANG AND J. S. UME, Sensitivity analysis for parametric completely generalized nonlinear implicit quasivariational inclusions, J. Math. Anal. Appl. 277 (2003), 142-154.

[14] Z. LiU, L. DeBnath, S. M. KANG AND J. S. UmE, Generalized mixed quasi-variational inclusions and generalized mixed resolvent equations for fuzzy mappings, Appl. Math. Comput. 149 (2004), 879-891.

[15] Z. LIU, S. M. KANG AND J. S. UME, On general variational inclusions with noncompact valued mappings, Adv. Nonlinear Var. Inequal. 5 no. 2 (2002), 11-25. 
[16] Z. LiU, S. M. KANG AND J. S. UME, Generalized variational inclusions for fuzzy mappings, Adv. Nonlinear Var. Inequal. 6 (2003), 31-40.

[17] Z. LiU, S. M. KANG AND J. S. UME, The solvability of a class of quasi-variational inequalities, Adv. Nonlinear Var. Inequal. 6 no. 2 (2003), 69-78.

[18] Z. LIU, S. M. KANG, Generalized multivalued nonlinear quasi-variational inclusions, Math. Nachr. 253 (2003), 45-54.

[19] Z. LIU, S. M. KANG AND J. S. UME, Completely generalized multivalued strongly quasivariational inequalities, Publ. Math. Debrecen 62 no. 1-2 (2003), 187-204.

[20] Z. LIU, S. M. KANG, Convergence and stability of perturbed three-step iterative algorithm for completely generalized nonlinear quasi-variational inequalities, Appl. Math. Comput. 149 (2004), 245-258.

[21] Z. LIU, J. S. UME AND S. M. KANG, General strongly nonlinear quasi-variational inequalities with relaxed Lipschitz and relaxed monotone mappings, J. Optim. Theory Appl. 114 no. 3 (2002), 639-656.

[22] Z. LIU, J. S. UME AND S. M. KANG, Resolvent equations technique for general variational inclusions, Proc. Japan Acad., Ser. A 78 no. 10 (2002), 188-193.

[23] Z. LIU, J. S. UME AND S. M. KANG, Completely generalized quasi-variational inequalities, Adv. Nonlinear Var. Inequal. 7 no. 1 (2004), 35-46.

[24] P. D. Panagiotopoulos, G. E. Stavroulakis, New types if variational principles based on the notion of quasidifferentiability, Acta Mech. 94 (1992), 171-194.

[25] J. PARIDA, A. SEN, A variational-like inequality for multifunctions with applications, J. Math. Anal. Appl. 124 (1987), 73-81.

[26] G. TIAN, Generalized quasi variational inequality problem, Math. Oper. Res. 18 (1993), 752-764.

[27] R. U. VERMA, On generalized variational inequalities involving relaxed Lipschitz and relaxed monotone operators, J. Math. Anal. Appl. 213 (1997), 387-392.

[28] R. U. VERMA, Generalized variational inequalities and associated nonlinear equations, Czechoslovak Math. J. 48 (1998), 413-418.

[29] R. U. Verma, Generalized pseudo-contractions and nonlinear variational inequalities, Publ. Math. Debrecen 53 (1998), 23-28.

[30] R. U. VERMA, The solvability of a class of generalized nonlinear variational inequalities based on an iterative algorithm, Appl. Math. Lett. 12 (1999), 51-53.

[31] R. U. VERMA, A general iterative algorithm and solvability of nonlinear quasivariational inequalities, Adv. Nonlinear Var. Inequal. 4 (2001), 79-87.

[32] J. C. YAO, Existence of generalized variational inequalities, Opera. Res. Lett. 15 (1994), 35-40.

[33] J. C. YAO, The generalized quasi variational inequality problem with applications, J. Math. Anal. Appl. 158 (1991), 139-160. 